\title{
Hypoleptinemia in patients with anorexia nervosa: loss of circadian rhythm and unresponsiveness to short-term refeeding
}

\author{
J L Balligand ${ }^{1,3}$, S M Brichard ${ }^{2}$, V Brichard ${ }^{1}$, J P Desager ${ }^{3}$ and M Lambert ${ }^{1}$ \\ ${ }^{1}$ Division of General Internal Medicine, ${ }^{2}$ Units of Endocrinology and Metabolism, and ${ }^{3}$ Pharmacotherapy, University of Louvain Medical School and \\ Cliniques Universitaires Saint-Luc, Avenue Hippocrate 10, 1200 Brussels, Belgium
}

(Correspondence should be addressed to M Lambert, Department of Internal Medicine, University of Louvain Medical School, Avenue Hippocrate 10, B-1200 Brussels, Belgium)

\begin{abstract}
Leptin is a protein encoded by the $\boldsymbol{o b}$ gene that is expressed in adipocytes and regulates eating behavior via neuroendocrine mechanisms. Plasma leptin levels have been shown to correlate with weight and body fat in normal, obese and anorexic subjects. In the last of these populations, the dynamic profile of plasma leptin levels during short-term refeeding has never been assessed. We thus investigated basal plasma leptin levels in 29 female patients with anorexia nervosa (AN) (age 21.9 \pm 1.4 years, body mass index (BMI) $15.2 \pm 0.3 \mathrm{~kg} / \mathrm{m}^{2}$ ) and in 80 normal female controls (age $21.2 \pm 0.2$ years, BMI $20.3 \pm 0.3 \mathrm{~kg} / \mathrm{m}^{2}$, mean \pm S.E.M.). Basal plasma leptin levels in AN were decreased by $77 \%$ compared with controls $(2.5 \pm 0.2$ vs $11.1 \pm 0.7 \mathrm{ng} / \mathrm{ml}, P<0.0001)$. In both AN subjects and controls, plasma leptin levels correlated significantly with BMI $\left(r^{2}=0.448, P<0.0001\right.$ and $r^{2}=0.339, P<0.0001$ respectively). Five AN patients (four female, one male, age $22.0 \pm 4.7$ years, BMI $14.2 \pm 0.4 \mathrm{~kg} / \mathrm{m}^{2}$, body fat $4.3 \pm 0.9 \mathrm{~kg}$ or $11.0 \pm 1.9 \%$ of body weight, basal metabolic rate (BMR) $958 \pm 122 \mathrm{kcal} /$ day) were studied during a 3-day refeeding period and compared with eight control subjects (two male, six female, age $25.7 \pm 1.2$ years, BMI $21.3 \pm 0.8 \mathrm{~kg} / \mathrm{m}^{2}$, body fat $15.1 \pm 0.9 \mathrm{~kg}$ or $24.6 \pm 1.7 \%$, BMR $1455 \pm 78 \mathrm{kcal} /$ day) submitted to 36 -h fasting. The amount of calories administered was based on BMR $+20 \%$ (carbohydrate $60 \%$, protein $17 \%$, fat $23 \%$ ). In contrast to the rise in leptin levels that occurred during refeeding after a prolonged fast period in normal subjects, plasma leptin levels remained low and unchanged throughout the 3 days of renutrition in AN patients. The circadian rhythm of leptin was also completely abolished. This contrasted with the preserved circadian variations of cortisol, whose mean levels were increased. In conclusion, we confirmed that plasma leptin levels are low in AN and correlate with body weight. We further demonstrated that plasma leptin levels do not respond to short-term refeeding in anorexic patients in whom circadian variations are not restored, which suggests that the acute regulation of leptin by positive changes in energy balance is not preserved under a critical threshold of body fat.
\end{abstract}

European Journal of Endocrinology 138 415-420

\section{Introduction}

The secretion of leptin, a hormone which is encoded by the $o b$ gene and plays a key role in weight maintenance, is subject to dual control. Under chronic conditions of steady-state energy balance, leptin is a static index of the amount of triglycerides stored in adipose tissue. Under non-steady-state energy balance situations, leptin may be acutely regulated by hormonal or nutritional changes independently of the available adipose tissue triglyceride stores, and serves as a sensor of energy balance (1).

Anorexia nervosa (AN) is characterized by behavioral manifestations including chronic self-starvation and severe weight loss, mainly at the expense of adipose tissue (2). Plasma leptin levels are reduced in association with low weight and body fat in anorexic patients (3-6), suggesting that the chronic regulation of leptin by adipose tissue stores is maintained even at an extreme of low body fat (4). In normal individuals, the acute regulation of leptin by changes in energy balance explains why short-term fasting results in a dramatic fall in leptin concentrations which rapidly reincrease during acute refeeding, while fat mass barely varies (7). It is still unknown whether this acute regulation of leptin (in particular, the response to positive changes in energy balance) is preserved under a critical threshold of body fat.

In the present study, we therefore evaluated the potential response of leptin to short-term refeeding in 
severely anorexic patients. We also examined whether the circadian rhythm of leptin levels (8) is preserved in this situation of undernutrition, and we compared the dynamic profile of leptin to that of cortisol and thyrotropin (TSH), two other hormones which are known to be secreted in a pulsatile manner.

\section{Subjects and methods}

\section{Basal measurements of plasma leptin concentrations}

Morning plasma samples were collected from 29 patients with AN who strictly met the criteria defined in the revised Diagnostic and Statistical Manual of Mental Disorders (9), and from 80 medical students.

\section{Study of the effect of short-term refeeding on plasma leptin, cortisol and TSH concentrations}

Five anorexic patients were studied before and during refeeding by the parenteral $(n=4)$ or enteral $(n=1)$ route for 3 days. Eight age- and sex-matched normal volunteers underwent a $36-\mathrm{h}$ fasting period after which they were refed with pre-prepared hospital meals. At the beginning of the study, body mass index (BMI) was calculated, body fat measured by bioelectric impedance, and basal metabolic rate (BMR) determined by indirect calorimetry using a metabolic monitor (Deltatrac, Datez, Helsinki, Finland). For refeeding, the amount of calories administered both to patients with $\mathrm{AN}$ and to controls was based on BMR $+20 \%$ with a nutrient composition of $60 \%$ carbohydrate, $17 \%$ protein and $23 \%$ fat. Plasma samples were collected at 0200, 0800 and $1400 \mathrm{~h}$ every day. The presence of a diurnal rhythm was defined as a significant difference in hormone levels between 1400 and $0200 \mathrm{~h}$ (leptin and TSH) or 0800 and $0200 \mathrm{~h}$ (cortisol).

\section{Hormone assays}

In all experiments, plasma was rapidly obtained by refrigerated centrifugation $\left(4^{\circ} \mathrm{C}\right)$ and stored at $-20^{\circ} \mathrm{C}$ until the assay. Serum leptin was measured using a human leptin RIA kit (DRG, Marburg, Germany). The sensitivity of the assay was $0.5 \mathrm{ng} / \mathrm{ml}$ and the limit of linearity $100 \mathrm{ng} / \mathrm{ml}$. The inter-assay variability was 6.8 and $5.1 \%$ at 2.9 and $13.7 \mathrm{ng} / \mathrm{ml}$ respectively. Intraassay variability was 8.3 and $3.9 \%$ at 4.9 and $10.4 \mathrm{ng} /$ $\mathrm{ml}$ respectively. Serum cortisol was measured by RIA in an antibody-coated tube assay (Corticot, ICN, Orangeburg, NY, USA). Intra-assay variability was 1.8 and $2.9 \%$ at 213 and $1132 \mathrm{nmol} / \mathrm{l}$ respectively; inter-assay variability was 5.6 and $5.1 \%$ at 196 and $1227 \mathrm{nmol} / \mathrm{l}$ respectively. Serum TSH levels were measured by IRMA (Riabead II, Abbott, IL, USA). Intra-assay variation was $5.4,1.7$ and $1.6 \%$ at $0.6,5.6$ and $19.6 \mu \mathrm{U} / \mathrm{ml}$ respectively; inter-assay variability was $6.3,5.9,4.4$ and $3.5 \%$ at $0.16,0.75,5.4$ and $19.6 \mu \mathrm{U} / \mathrm{ml}$ respectively. Plasma insulin levels were measured by RIA using human insulin (Peptide Institute, Inc., Osaka, Japan) as a standard, with a limit of sensitivity of $6 \mu \mathrm{U} / \mathrm{ml}$.

\section{Statistics}

Results are given as the means \pm s.E.M. Repeated measures of ANOVA followed by the Newman-Keuls test and Student's $t$-tests for paired and unpaired data were used to analyze differences within and between the anorexic and control groups. A regression model of simple order was used to determine the relation between plasma leptin concentrations and BMI. $P<0.05$ was considered significant.

\section{Results}

\section{Basal plasma levels of leptin in anorexic patients and controls}

The measurements were performed in 29 female patients with AN (age 21.9 \pm 1.4 years, BMI $15.2 \pm$ $0.3 \mathrm{~kg} / \mathrm{m}^{2}$ ) and in 80 normal female controls (age $21.2 \pm 0.2$ years, BMI $20.3 \pm 0.3 \mathrm{~kg} / \mathrm{m}^{2}$ ). Basal plasma leptin levels were decreased by $77 \%(P<0.0001)$ in anorexic patients $(2.5 \pm 0.2 \mathrm{ng} / \mathrm{ml})$ compared with controls $(11.1 \pm 0.7 \mathrm{ng} / \mathrm{ml})$. Plasma leptin levels significantly correlated with BMI in anorexic patients $\left(r^{2}=0.448, \quad P<0.0001\right)$ and control subjects $\left(r^{2}=0.339, P<0.0001\right)$.

\section{Effect of short-term refeeding on plasma leptin, TSH and cortisol levels in control subjects and anorexic patients}

The influence of refeeding was evaluated in five anorexic patients and eight control subjects. The latter group had been previously submitted to a 36-h fasting period. The clinical characteristics of the two groups (recorded at the beginning of the study, i.e. during spontaneous low caloric intake for $\mathrm{AN}$ and before fasting for controls) are summarized in Table 1. As expected, mean values of BMI, body fat mass and BMR before refeeding were lower in AN patients compared with control subjects (Table 1). After refeeding, there was a marginal increase in $\mathrm{BMI}$ in $\mathrm{AN}$ patients (from $14.2 \pm 0.4$ to $14.9 \pm 0.2 \mathrm{~kg} / \mathrm{m}^{2}, P<0.05$ ) and no change in BMI in controls (from 21.3 \pm 0.8 to $21.1 \pm 0.8 \mathrm{~kg} / \mathrm{m}^{2}$ ).

Figure 1 illustrates the changes in hormone levels in control subjects. Plasma leptin levels exhibited circadian variations with maximal values around $0200 \mathrm{~h}$, as described (8). Fasting for $36 \mathrm{~h}$ decreased leptin levels by $70 \%$, and the values reached at the end of this period were not statistically different from those found 
Table 1 Clinical characteristics (mean \pm S.E.M.) of patients with anorexia nervosa (AN) and control subjects included in the refeeding study.

\begin{tabular}{lcc}
\hline & AN $(n=5)$ & Control $(n=8)$ \\
\hline Sex ratio (male/female) & $1 / 4$ & $2 / 6$ \\
Age (years) & $22.0 \pm 4.7$ & $25.7 \pm 1.2$ \\
BMl (kg/m $\left.\mathrm{m}^{2}\right)$ & $14.2 \pm 0.4$ & $21.3 \pm 0.8^{* * *}$ \\
Body fat mass $(\mathrm{kg})$ & $4.3 \pm 0.9$ & $15.1 \pm 0.9^{\star * *}$ \\
Body fat mass (\%) & $11.0 \pm 1.9$ & $24.6 \pm 1.7^{\star *}$ \\
BMR (kcal/day) & $958 \pm 122$ & $1455 \pm 78^{*}$
\end{tabular}

These characteristics were recorded before refeeding (i.e. during spontaneous low caloric intake for $\mathrm{AN}$ and before fasting for controls). ${ }^{*} P<0.01,{ }^{* *} P<0.001,{ }^{* *} P<0.0001$. in patients with AN. Refeeding healthy volunteers produced an acute rise in mean leptin levels, with reappearance of circadian oscillations. The diurnal rhythm of TSH was rather similar to that of leptin (nocturnal surge at $0200 \mathrm{~h}$ and attenuation by fasting). In contrast, the circadian variations of cortisol were inversely related to those of leptin (10) and TSH, with maximal levels peaking at $0800 \mathrm{~h}$, and were not influenced by the acute nutritional changes. Mean levels of plasma insulin were low during fasting (mean values from all time points during the $36-\mathrm{h}$ fasting, $7.7 \pm 0.5 \mu \mathrm{U} / \mathrm{ml}$ ) and reached $14 \pm 2.7 \mu \mathrm{U} / \mathrm{ml}$ during refeeding (not shown).

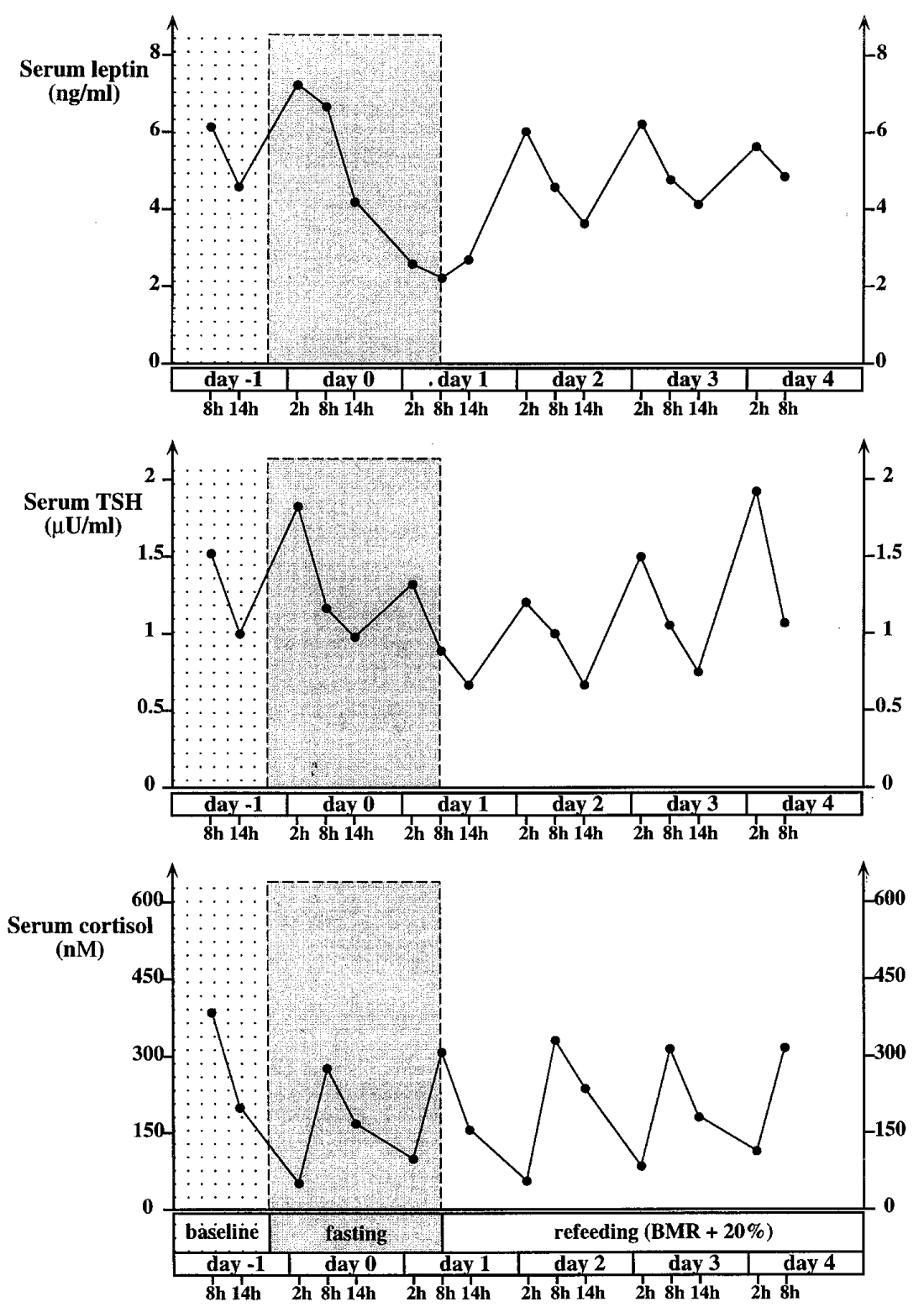

Figure 1 Influence of refeeding for 3 days on plasma leptin, TSH and cortisol levels in eight healthy volunteers who had been previously submitted to a 36 - $\mathrm{h}$ fasting period from $2000 \mathrm{~h}$ on day 1 (i.e. after the evening meal) up to $0800 \mathrm{~h}$ on day +1 (i.e. after blood sampling). For refeeding, the amount of calories administered was based on BMR $+20 \%$, with a nutrient composition of $60 \%$ carbohydrate, $17 \%$ protein, $23 \%$ fat. 


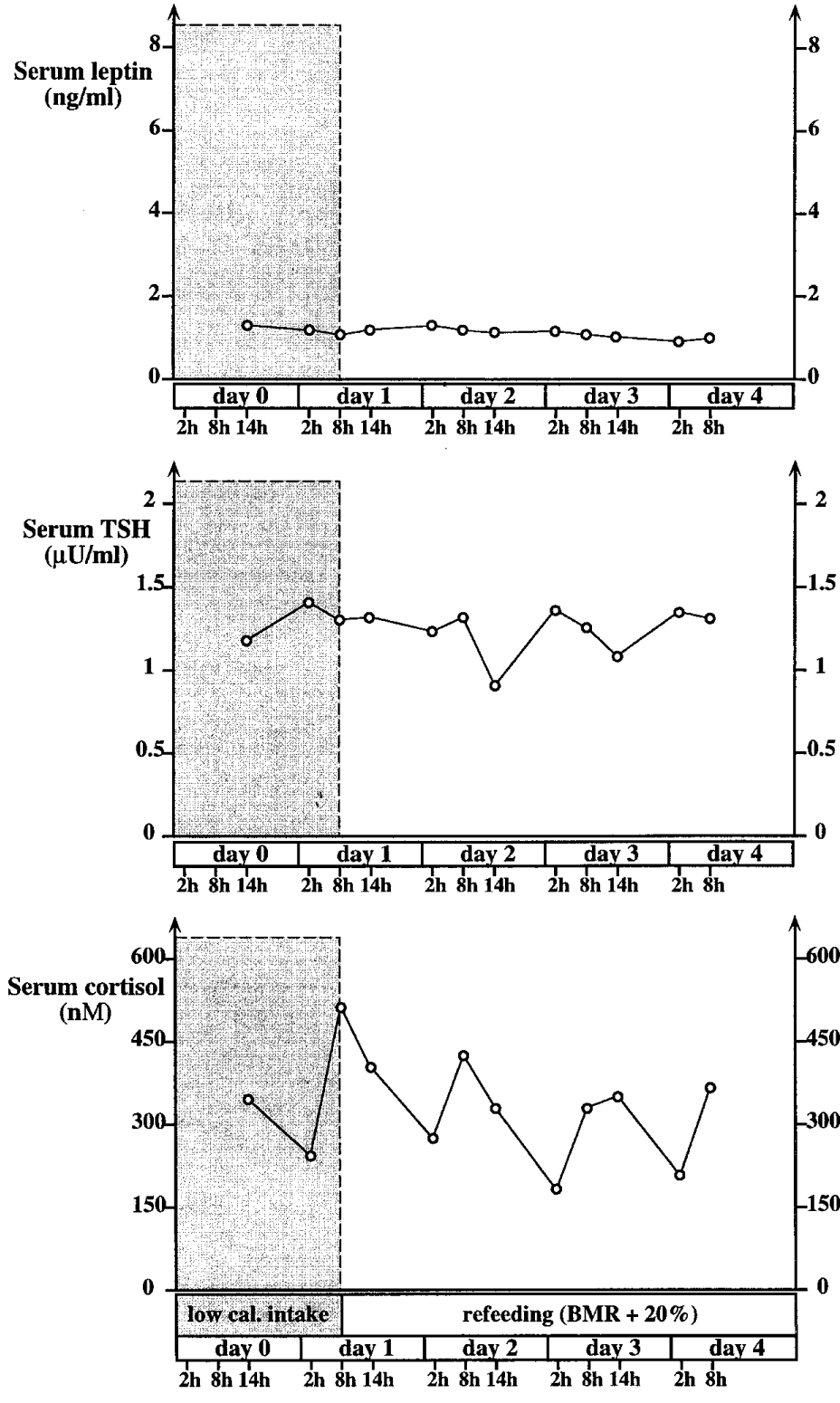

Figure 2 Influence of refeeding for 3 days on plasma leptin, TSH and cortisol levels in five severely anorexic patients, in whom spontaneous low caloric intake was $425 \pm 24 \mathrm{kcal} /$ day (day 0 ). For refeeding, the amount of calories administered was based on BMR $+20 \%$, with a nutrient composition of $60 \%$ carbohydrate, $17 \%$ protein, $23 \%$ fat.
Figure 2 illustrates the changes in hormone levels in patients with AN. Mean plasma leptin levels were lower at baseline than in control subjects, as previously observed (this study; 3-6), and did not exhibit any circadian variations. Moreover, acute refeeding (parenteral or enteral) did not produce any rise in plasma leptin and did not restore any circadian variation. Unlike leptin, mean cortisol levels in anorexic patients (average values at each time point, $335 \pm 27 \mathrm{nmol} / \mathrm{l}$ ) were higher $(P<0.01)$ than in control subjects $(204 \pm 27 \mathrm{nmol} / \mathrm{l})$ and exhibited physiological variations with a peak at $0800 \mathrm{~h}$. Mean TSH concentrations were not different in anorexic and control subjects, but the diurnal oscillations were altered in AN (no significant changes over time by multiple ANOVA). Mean insulinemia was low during decreased spontaneous low calorie intake $(6.7 \pm 0.3 \mu \mathrm{U} / \mathrm{ml})$ and reached $14.9 \pm 3.4 \mu \mathrm{U} / \mathrm{ml}$ during refeeding (not shown). In contrast to acute refeeding, in two of the five anorexic patients who substantially regained weight $(\sim 10 \mathrm{~kg})$ within 2-3 months after discharge, basal plasma leptin levels were fully normalized $(\sim 10 \mathrm{ng} / \mathrm{ml})$, in agreement with very recent reports $(5,11,12)$.

\section{Discussion}

We confirmed that basal leptin levels are low in AN, and correlate with BMI $(3-6,11)$. This observation leads to the hypothesis that chronic regulation of leptin by adipose tissue stores was maintained even at an extreme of low weight and body fat (4). 
In the present study, we further showed that acute responsiveness of leptin to short-term refeeding is abolished in AN. This contrasts with the acute rise of leptin produced by refeeding in healthy volunteers, whose leptinemia has been previously decreased by fasting to concentrations similar to those in AN. Acute differences in the pre-refeeding status (i.e. 36-h fasting in control subjects vs spontaneous low caloric intake in anorexic patients) may not entirely account for this discrepancy, since fasting is not a pre-requisite for inducing a rise in leptin levels in response to acute positive changes in energy balance. Accordingly, the overfeeding for $12 \mathrm{~h}$ of healthy volunteers not previously submitted to prolonged fasting did produce a $40 \%$ increase in plasma leptin concentrations (13). In addition, the difference between control subjects and anorexic patients may not be explained by the effect of parenteral vs enteral refeeding because in the single anorexic patient who was refed orally, leptin levels also did not increase. Moreover, leptin mRNA and serum concentrations were stimulated equally by enteral and intravenous administration of similar amounts of calories in rats (14). The unresponsiveness of leptin to acute refeeding in anorexic patients is reminiscent of the very marginal change in $o b$ mRNA produced by acute insulin treatment in severely diabetic and catabolic rats (15). Taken together, these data suggest that the acute regulation of leptin by positive (nutritional, hormonal etc.) changes in energy balance is not preserved under a critical threshold of body fat. This appears teleologically meaningful. If these changes occurring after a period of severe or long-fasting catabolism were rapidly enhancing the expression of $o b$ gene and leptin secretion, the subsequent anorexia and increased energy expenditure would prevent rebuilding of fat-free mass and energy stores.

The circadian variations of leptin, which have been evidenced in both normal-weight and obese subjects (8), were also completely abolished in all anorexic patients. Likewise, the diurnal rhythm of leptin levels was lost in amenorrheic athletes (16), a physiological model of increased energy expenditure and depleted body fat mass, though to a lesser degree than in AN (total body fat $9 \mathrm{~kg}$ (16) vs $4.3 \mathrm{~kg}$ in this study). In order to conserve metabolic fuels, anorexic patients, like athletes, have developed adaptative responses to chronic starvation such as reproductive dysfunction, hypercortisolemia and hypothyroidemia (17). The administration of leptin blunts most of the neuroendocrine responses in food-deprived mice, produces a striking reversal of the suppression of the estrus cycle, attenuates the activation of the hypothalamicpituitary-adrenal axis and restores the impaired thyroid function $(18,19)$. These observations suggest that some of the endocrine disturbances in chronic undernutrition, and more particularly in AN, may result from leptin deficiency (i.e. low leptin levels and loss of pulsatility).
Alternatively, metabolic or endocrine abnormalities associated with chronic weight loss may contribute to or maintain hypoleptinemia. Since insulin levels in AN patients before refeeding were similar to those in fasted control subjects in our study, the chronic hypoinsulinemia characteristic of AN (17) may have played a role $(20,21)$. However, none of the two hormones measured in our study because of their known circadian rhythm are likely to be involved. Tri-iodothyronine administration to hypothyroid rats actually resulted in a rapid decrease in $o b$ mRNA (22). Glucocorticoids have been shown to potently stimulate $o b$ gene expression and leptin secretion in rats and in man, both in vivo and in vitro (23-25). The observation of low and unresponsive leptin levels in spite of high glucocorticoid concentrations in anorexic patients reinforces the hypothesis that the stimulation of $o b$ gene and leptin synthesis requires a critical threshold of body fat mass. Finally, the sympathetic nervous tone, which is decreased in AN (17), is also an unlikely contributor because catecholamines and cAMP actually decreased $o b$ gene expression and leptin levels (26).

In conclusion, we confirmed that plasma leptin levels are low in AN and correlate with body weight. We further demonstrated that plasma leptin levels do not respond to short-term refeeding in anorexic patients, which suggests that the acute regulation of leptin by positive changes in energy balance is not preserved under a critical threshold of body fat. Finally, we also showed that plasma leptin levels do not exhibit any circadian variation. This loss of pulsatility in association with low leptin levels may contribute to some of the endocrine disturbances in AN.

\section{Acknowledgements}

We are grateful to Prof. Ph Denayer for cortisol and TSH measurements, and to Prof. J-M Ketelslegers for insulin measurements. This work was supported by a grant from the Fonds de la Recherche Scientifique of the Catholic University of Louvain (FDS 1996) and a grant from the Fonds National de la Recherche Scientifique (FNRS) (Crédit aux Chercheurs 1997). SMB is chercheur qualifié of the FNRS. JLB and SMB contributed equally to this work.

\section{References}

1 Caro JF, Sinha MK, Kolaczynski JW, Zhang PL \& Considine RV. Leptin: the tale of an obesity gene. Diabetes $1996451455-$ 1462.

2 Lambert M, Hubert C, Depresseux G, Vande Berg B, Thissen JP, Nagant de Deuxchaisnes Ch et al. Hematological changes in anorexia nervosa are correlated with total body fat mass depletion. International Journal of Eating Disorders 199721 329-334.

3 Herebrand J, van der Heyden J, Devos R, Kopp W, Herpertz S \& Remschmidt H. Plasma concentrations of obese protein in anorexia nervosa. Lancet 1995346 1624-1625. 
4 Grinspoon S, Gulick T, Askari H, Landt M, Lee K, Anderson E et al. Serum leptin levels in women with anorexia nervosa. Journal of Clinical Endocrinology and Metabolism 199681 3861-3863.

5 Mantzoros Ch, Flier JS, Lesem MD, Brewerton TD \& Jimerson DC. Cerebrospinal fluid leptin in anorexia nervosa: correlation with nutritional status and potential role in resistance to weight gain. Journal of Clinical Endocrinology and Metabolism 199782 18451851.

6 Ferron F, Considine RV, Peino R, Lado IG, Dieguez C \& Casanueva FF. Serum leptin concentrations in patients with anorexia nervosa, bulimia nervosa and non-specific eating disorders correlate with the body mass index but are independent of the respective disease. Clinical Endocrinology 199746 289-293.

7 Kolaczynski JW, Considine RV, Ohannesian J, Marco C, Opentanova I, Nyce MR et al. Responses of leptin to short-term fasting and refeeding in human: A link with ketogenesis but not ketones themselves. Diabetes $1996451511-1515$.

8 Sinha MK, Ohannesian JP, Heiman ML, Kriaciunas A, Stephens TW, Magosin S et al. Nocturnal rise of leptin in lean, obese and non-insulin-dependent diabetes mellitus subjects. Journal of Clinical Investigation 199697 1344-1347.

9 American Psychiatric Association. Diagnostic and Statistical Manual of Mental Disorders: DSM-III-R, 3rd edn. Washington DC: American Psychiatric Association, 1987.

10 Licinio J, Mantzoros C, Negrao AB, Cizza G, Wong ML, Bongiorno $\mathrm{PB}$ et al. Human leptin levels are pulsatile and inversely related to pituitary-adrenal function. Nature Medicine 19973 575-579.

11 Casanueva FF, Dieguez C, Popovic V, Peino R, Considine RV \& Caro JF. Serum immunoreactive leptin concentrations in patients with anorexia nervosa before and after partial weight recovery. Biochemical and Molecular Medicine 199760 116-120.

12 Herebrand J, Blum WF, Barth N, Coners H, Englaro P, Juul A et al. Leptin levels in patients with anorexia nervosa are reduced in the acute stage and elevated upon short-term weight restoration. Molecular Psychiatry 19972 130-134.

13 Kolaczynski JW, Ohannesian JP, Considine RV, Marco CC \& Caro JF. Response of leptin to short-term and prolonged overfeeding in humans. Journal of Clinical Endocrinology and Metabolism 199681 4162-4165.

14 Levy R, Legallsalmon E, Santos M, Pandak WM \& Stevens W. Effect of enteral versus parenteral nutrition on leptin gene expression and release into the circulation. Biochemical and Biophysical Research Communications 1997237 98-102.
15 Becker DJ, Ongemba LN, Brichard V, Henquin JC \& Brichard SM. Diet- and diabetes-induced changes of ob gene expression in rat adipose tissue. FEBS Letters $1995371324-328$.

16 Laughlin GA \& Yen SSC. Hypoleptinemia in women athletes: absence of a diurnal rhythm with amenorrhea. Journal of Clinical Endocrinology and Metabolism 199782 318-321.

17 Warren MP. Anorexia nervosa. In Endocrinology, pp 2679-2691. Ed. LJ DeGroot. Philadelphia: WB Saunders, 1995.

18 Ahima RS, Prabakaran D, Mantzoros C, Qu DQ, Lowell B, Maratos-Flier E et al. Role of leptin in the neuroendocrine response to fasting. Nature $199727588-90$.

19 Schwartz MW \& Seeley RJ. Neuroendocrine responses to starvation and weight loss. New England Journal of Medicine $19973361802-1811$.

20 Cusin I, Sainsbury A, Doyle P, Rohner-Jeanrenaud F \& Jeanrenaud B. The ob gene and insulin. A relationship leading to clues to the understanding of obesity. Diabetes 199544 1467-1470.

21 Kolaczynski JW, Nyce MR, Considine RV, Boden G, Nolan JJ, Henry $\mathrm{R}$ et al. Acute and chronic effect of insulin on leptin production in humans. Studies in vivo and in vitro. Diabetes 1996 45 699-701.

22 Fain JN, Coronel EC, Beauchamp MJ \& Bahouth SW. Expression of leptin and $\beta_{3}$-adrenergic receptors in rat adipose tissue in altered thyroid states. Biochemical Journal 1997322 145-150.

23 De Vos P, Saladin R, Auwerx J \& Staels B. Induction of ob gene expression by corticosteroids is accompanied by body weight loss and reduced food intake. Journal of Biological Chemistry 1995270 15958-15961.

24 Larsson H \& Ahren B. Short-term dexamethasone treatment increases plasma leptin independently of changes in insulin sensitivity in healthy women. Journal of Clinical Endocrinology and Metabolism 199681 4428-4432.

25 Reul BA, Ongemba LN, Pottier AM, Henquin JC \& Brichard SM. Insulin and insulin-like growth factor 1 antagonize the stimulation of ob gene expression by dexamethasone in cultured rat adipose tissue. Biochemical Journal 1997324 605-610.

26 Giacobino JP. Role of the $\beta 3$-adrenoceptor in the control of leptin expression. Hormone and Metabolism Research 199628 633637 .

Received 12 November 1997

Accepted 12 January 1998 